Article

\title{
Rural Residents' Perception of Construction Project Delays in Pakistan
}

\author{
Shahid Hussain ${ }^{1, *}$ (D) , Fangwei Zhu ${ }^{1, *}$, Zaigham Ali ${ }^{2}$ and Xiaohang $\mathrm{Xu}^{3}$ \\ 1 Faculty of Management and Economics, Dalian University of Technology, Dalian 116024, China \\ 2 Department of Business Management, Karakoram International University, Gilgit-Baltistan 15100, Pakistan; \\ zaigham.ali@kiu.edu.pk \\ 3 School of Built Environment, University of Technology Sydney, Broadway, NSW 2007, Australia; \\ xiaohang.xu@student.uts.edu.au \\ * Correspondence: shahidkhoja@mail.dlut.edu.cn (S.H.); zhufw@dlut.edu.cn (F.Z.); Tel.: +86-41-8470-7746 (F.Z.)
}

Received: 22 October 2017; Accepted: 16 November 2017; Published: 20 November 2017

\begin{abstract}
The construction industry is one of the key sectors that facilitate sustainable economic and social development in the region. Currently, community development mechanisms are adopted by many developed and developing nations, aimed at enhancing economic growth and quality of life along with social welfare of the local community. This study reviews the rural residents' perception of public construction project delays and aims to explore economic and social challenges confronted by residents, especially in rural areas in Pakistan. A questionnaire with 26 factors identified from the literature was sent to rural educated residents. Through a questionnaire survey, the opinions of rural residents were sought and tested. Based on 366 (73\%) valid responses, this study examined the socio-economic influencing factors. The findings of the study revealed that problems faced while traveling, increase the price of consumer goods, high transportation costs, lack of educational opportunities, more expenditures on education, and barriers to primary healthcare access were the top most important factors. Research results confirmed that the delays in construction projects negatively affect the socio-economic conditions of the rural community, which directly influence the rural dwells' sustainable life. The research findings suggest that the practitioners in public sector organization make sure to execute the project on time and within the quality. Otherwise, it has negative socio-economic implications for the rural community.
\end{abstract}

Keywords: rural community; economic and social; infrastructure projects; delays; sustainable rural development; Pakistan

\section{Introduction}

It is generally agreed that public sector construction projects are seen as an economic and social engine for sustainable rural community development that promotes the well-being of rural residents. In most developing countries, government spending on infrastructure projects is considered a significant component of development budget [1]. Government purpose to spend money on public infrastructure projects to enhancing productivity growth, local business growth, agriculture growth, easy access to the marketplaces, better health centers, quality education, and poverty alleviation, which are attractive win-win strategies [2]. In these societies, inferior infrastructure conditions substantially influence the quality of education, better health facilities, electric power distribution, water supply, telecommunications services and appropriate sanitation facilities [3]. However, the most significant project success criteria are not only meeting time, cost, and quality objectives of the projects but also the standard of meeting the community needs [4,5].

The contribution made by infrastructure is a vital element in the development of rural areas and the growth of rural economy. However, most of the public sector projects in developing countries 
experience extensive delays and thereby exceed initial time [6]. The delay in completion of public infrastructure projects negatively impacts on both economic and social aspects such as enhancing workforce skills, poverty eradication, extension services to education, agricultural growth [7-9], sustainable development [10] and maintaining sustainable communities [11], especially in developing countries. Although several studies examining the causes or the effects of project delays in the construction industry have been conducted globally $[6,12,13]$ the impact of project delay is concentrated only on contracting parties (owner, contractor, and consultant). However, the impact of construction delays is not limited to the construction industry, but also affects the overall economic and social condition in the region. Nevertheless, a dearth of research considers the perception of the ultimate beneficiaries of the project, who suffer the most from these delays. Hence, this study aims to examine the rural residents' perception of public sector construction project delays and also to identify the difficulties, hurdles, and challenges confronted by the rural community.

The paper is structured as follows. Section 2 describes the literature review; Section 3 presents research methodology; and Section 4 explains research data. Section 5 describes data analysis, and Section 6 discusses the findings from the analysis. Finally, Section 7 presents the conclusion.

\section{Literature Review}

The authors revealed and addressed two strands of literature. The first considers the importance and benefits of infrastructure projects, and the second explicitly examines the causes and effects of construction project delays.

\subsection{Importance and Benefits of Infrastructure Projects}

To address the importance and benefits of infrastructure projects, a large number of research papers on the project benefits to societies have been conducted in many countries. Sahoo and Dash [14] examined the role of infrastructure in accelerating economic growth in the four South Asian countries, and the findings revealed that infrastructure development contributes a significant role in economic growth in South Asia. Aschauer [15] explicitly explained why infrastructure is important, and how infrastructure projects can effectively expedite the quality of life necessities and enhancements in different ways, e.g., support better health, greater safety, recreational activities, economic opportunity and leisure, and also suggested that infrastructure investment will raise quality of life and improve performance of the economy. Sahoo et al. [16] investigated and explored that design an economic policy improves the physical infrastructure as well as human capital that plays a vital role in economic growth in developing countries such as China. Further, the results revealed that infrastructure development in China has a more important contribution to growth than both private and public investment. Calderón and Servén [17] provided an empirical assessment of the impact of infrastructure development on growth and inequality, with a focus on Sub-Saharan Africa. Their main conclusion has expanded the size of infrastructure stock, and better quality of infrastructure facility has a significant impact on economic growth. Shen et al. [7] studied that rural infrastructure plays an eminent role in economic development, agricultural growth, and poverty alleviation, especially in developing countries. Moreover, the authors identified eight critical assessment indicators for determining the benefits of investment in rural infrastructure.

Roads are important means of supporting communities to have easy movability, comfortable lives [18], alleviate poverty [19] and reduce transpiration cost [20-22] in rural areas. Modinpuroju et al. [23] studied facility-based planning methodology for rural roads using spatial techniques in India and suggested that improving rural roads reduces travel time on the road and enhances interaction between the habitations. Yuan et al. [24] investigated rural road investment and its importance in Fujian Province, China. The findings indicated that enhancements for reducing travel time raise the trip frequency of households as well as increase poor household income.

Doeksen et al. [25] found that rural hospitals played a significant role in poor households in rural areas and introduced economic health of a community by employing a community simulation 
model to a rural community in Oklahoma. Vaughan et al. [26] evaluated the importance of the hospital sector to the local economy. The results of the study indicated that hospitals perform an important share in the economic stability and regional community development. The school is the central social institution in most rural communities and played a significant role in the communal activities and pedagogical need of rural communities [27]. Dewees and Velázquez [28] concluded that rural schools not only facilitate the basic need of educational services to the students, but also facilitate citizenship, leadership, and problem-solving skills. In addition, school buildings are used for community meetings and development programs. Minta [29] proposes three important community development strategies that can contribute to the betterment of the civil society. Minta recommended that community members must have access to better education, housing, healthcare, and high-quality public goods.

\subsection{Previous Studies on the Causes and Effects of Delays in Construction Projects}

Various papers have been published in the past to identify the delay causes and effects of delay in construction projects. Gündüz et al. [30] and Hwang et al. [31] define delays in construction projects as the inability of accomplishing the schedule objectives, increased cost, interruption of work, loss of productivity, being behind schedule, disputes, third-party claims, termination of contracts and dissatisfaction of the primary stakeholders. Many construction projects for many years have experienced budget overspends [32], time extensions [33], and time overruns than the planned in the contract $[4,34]$, and sometimes the construction schedule completion date is double [12]. Most developing country construction project delays come from scarcities of public funds [35] in the current fiscal year.

Several previous studies were reviewed to identify causes and effects of delays in construction projects. For example, in Saudi Arabia, Assaf and Al-Hejji [36] concluded that 70\% of projects faced time overrun and observed that 45 out of 76 projects considered were delayed. Odeyinka and Yusif [37] revealed that 7 out of 10 construction projects surveyed in Nigeria experienced delays in their execution. The Ministry of Statistics and Programme Implementation in India showed that, out of 951 construction projects monitored, 474 projects were behind schedule and 309 projects had cost overruns [38]. Faridi and El-Sayegh [39] reported that 50\% of construction projects experienced delays in UAE construction industry.

In examining the delaying factors affecting the construction projects in the life-cycle process of building and road projects, Akogbe et al. [12] analyzed the delay factors in a construction project in Benin and recommended a managerial method that would be important for the success of new development projects. The paper concluded that the financial capability of the contractor and financial difficulties of owner are the leading causes of delay on projects in Benin under the responsibility of both owner and contractor. Kaliba et al. [13] have accomplished a study on cost escalation and schedule delays in road construction projects in Zambia, and found that main delay factors were under the client's responsibility, in which late payment, the financial process, and financial difficulties were the most significant factors. A study by Mahamid et al. [6] on a time performance of road construction projects in the West Bank in Palestine explored the views of contractor and consultant on causes of delays and revealed that contractor and consultant suffer from many problems which affect the project performance negatively. According to Larsen et al. [40], construction project schedule, budget, and quality is affected in significantly different ways in Denmark construction industry and found the lack of project funding, omissions in consultant material, and omissions in construction work to be the most critical factors affecting project time, cost, and quality. Odeh and Battaineh [41] studied the main causes of construction delay and explored that the extensive delays are the cause of costly disputes and claims among contractor and consultant. Manzoor Arain and Sui Pheng [42] researched the potential effects of variation orders on institutional building projects in Singapore and the results revealed an increase in project costs, delays in scheduled payment, and rework and demolition were the most significant factors affecting variation orders for institutional buildings. 
From the above literature review, it is clear that, worldwide, practitioners and researchers are paying attention to questions of the importance of public infrastructure projects for the socio-economic development of community, and causes and effects of construction project delays as well as their impact on the project parties (owner, contractor, consultant, etc.). There has been a lack of research on the impact of public construction project delays on the community. Because of adverse effects, there has been an increased importance on the notion of sustainable construction development; it is necessary to keep an eye on the local community needs and expectations during the delays in construction projects. To fill this knowledge gap, this study aims to reveal the critical economic and social challenges faced by the rural communities during delays in public construction projects in Pakistan. Public sector infrastructure projects are the main component in annual development budget of Pakistan. The government of Pakistan as a sole service provider plays a key role in the rural community for project initiation, planning, funding, implementation and overall management until completion. Starting from the need identification of the project at a particular area, community need is acknowledged; for instance, basic education, healthcare, electricity, and road infrastructure public projects are administrated by the government for the rural community. When it comes to delays in construction projects that can negatively impact economic and social sphere of rural communities' development, their issues are dealt with neither by the practitioners nor by the academician. This triggered to conduct this study in rural areas of Pakistan. According to the World Bank collection of Development Indicators 2016, 60.776\% of the population resides in rural areas in Pakistan. The basic amenities are lacking, and projects are facing severe delays. Thus, the challenge for the government of Pakistan is to evaluate the impact of project delays on economic and social conditions of the rural community. The conceptual model is shown in Figure 1.

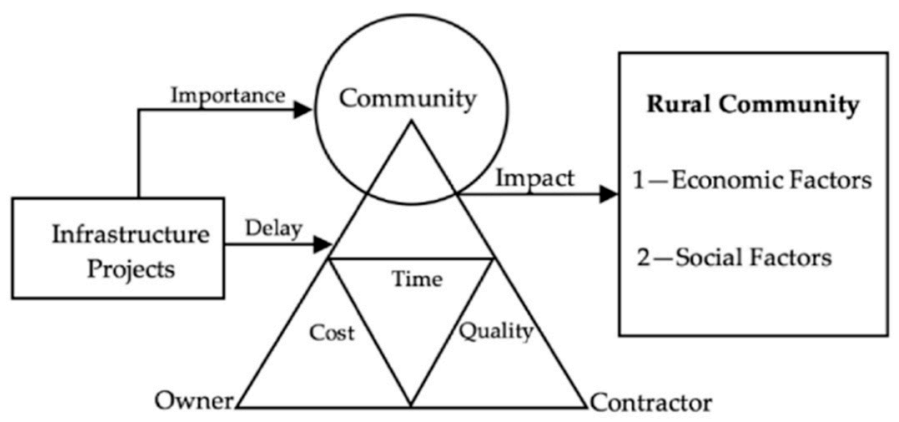

Figure 1. Conceptual model.

\section{Research Methodology}

The research objective of this study is to explore the factors during project delay that have a profound effect on the socio-economic conditions of the rural communities. A detailed literature review on the subject of this study is initially carried out to construct a theoretical understanding on the topic, which involved the use of information from journals, books, research theses, and conference proceedings, and periodicals are the secondary source of data relating to the research topic. This resulted in the identification of a preliminary list of the most important factors that frequently lead to influence the rural community sustainable life. These factors are used in a questionnaire to conduct the survey that is aimed to get the perception of rural residents. In total, more than 40 factors are initially found from various studies. Moreover, a pilot study is conducted to pre-test the survey with fourteen experts before the questionnaire is distributed and subsequently amended before a final version is shaped. The questionnaire is improved based on responses and suggestions from the experts. Some factors are added as appropriate for local situations, some factors are deleted, and some of these factors are common or interrelated. After consideration, 26 influencing factors are selected for the final survey to collect data about respondents' opinions on the relative importance of these factors. A simple random sampling method is used to collect data from the sample using a questionnaire. 
The respondents are asked to indicate the importance of each factor by using a Likert scale from 1 to 5 . The factors are classified into two categories: economic and social influencing factors.

By considering the influencing factors, data are gathered through a questionnaire survey, and the collected data are analyzed using Statistical Package for the Social Sciences (SPSS). First, a statistical tool SPSS is used to check the reliability of the collected data. Then, mean score and standard deviation for each factor are computed, leading to the finding of most critical influencing factors. Furthermore, the $t$-test and ANOVA test are used to verify the consistency of the opinions among different participants who have taken part in the survey process. Finally, the findings of the statistical analysis are interpreted to provide useful and valuable evidence to evaluate the critical influencing factors. In addition, five rural community leaders who have taken part in the pilot study for questionnaire survey are requested to further discuss the survey findings from data analysis, and valuable suggestions are obtained from the participants.

\section{Research Data}

\subsection{Primary List of Community Influencing Factors}

After administrating a pilot study, standard influencing factors affecting the community during public sector construction project delays are listed in Table 1. The factors are categorized into two groups: economic-related factors and social-related factors.

Table 1. Primary factors impact the community during the public construction project delays.

\begin{tabular}{|c|c|c|}
\hline S. No & Influencing Factors & Main Source \\
\hline \multicolumn{3}{|c|}{ Economic-Related Factors } \\
\hline 1 & High transportation costs (ECF_1) & {$[19,24,43,44]$} \\
\hline 2 & Increase costs of consumption and production of goods and services (ECF_2) & {$[45]$} \\
\hline 3 & More expenditures on education (ECF_3) & {$[46,47]$} \\
\hline 4 & Limit the use of local market to the sale of their produces (ECF_4) & {$[19,48]$} \\
\hline 5 & Decreases the income earning (ECF_5) & {$[19,49]$} \\
\hline 6 & Hindrance to business growth (ECF_6) & {$[50]$} \\
\hline 7 & Decrease agricultural production (ECF_7) & [51-53] \\
\hline 8 & Decline in farming incomes (ECF_8) & {$[19,54,55]$} \\
\hline 9 & Increases the price of consumer goods (ECF_9) & {$[20,45]$} \\
\hline 10 & Obstruct the business opportunities (ECF_10) & [17] \\
\hline 11 & Increases healthcare expenditures (ECF_11) & {$[56,57]$} \\
\hline 12 & Decreases in economic growth (ECF_12) & {$[8,19,58]$} \\
\hline 13 & Impacts on local market development (ECF_13) & [45] \\
\hline \multicolumn{3}{|c|}{ Social-Related Factors } \\
\hline 14 & Lack of access to urban areas (SOF_1) & {$[19,54]$} \\
\hline 15 & Problems faced while traveling (SOF_2) & {$[57]$} \\
\hline 16 & Decrease opportunities for community livelihood (SOF_3) & {$[59,60]$} \\
\hline 17 & Impact the living standard (SOF_4) & {$[17,49,61]$} \\
\hline 18 & Barriers to primary healthcare access (SOF_5) & {$[57,62]$} \\
\hline 19 & Lack of educational opportunities (SOF_6) & {$[49]$} \\
\hline 20 & Increase in travel time (SOF_7) & {$[19,63]$} \\
\hline 21 & Increases community healthcare issues (SOF_8) & {$[56]$} \\
\hline 22 & Difficulties in-time access to hospitals and educational institutions (SOF_9) & {$[19,64]$} \\
\hline 23 & Hurdles to higher academic achievement (SOF_10) & {$[65,66]$} \\
\hline 24 & Unbalanced educational development (SOF_- 11$)$ & {$[67]$} \\
\hline 25 & Decrease in school enrollment rates (Primary school-age children) (SOF_12) & [65] \\
\hline 26 & Suffer adult basic education (SOF_13) & [65] \\
\hline
\end{tabular}




\subsection{Questionnaire Design}

The questionnaire used for the survey is organized into two parts to test the rural respondents' perception. The first part of the questionnaire is related to the general information of the respondents (Age, Gender, Occupation, Education, and Area). In the second part of the questionnaire, the 26 questions are related to influencing factors. The rural community's respondents are requested to respond to the questions relating to their experience about the influence of delays in construction projects faced by them. The survey is developed based on five-point Likert scale for degree of the agreement described: 1 = Strongly disagree; 2 = Disagree; 3 = Neither agree nor disagree; $4=$ Agree; and $5=$ Strongly agree.

\subsection{Population and Sample Size}

The sample is limited to communities in rural areas in Pakistan. Targeted respondents were educated rural residents holding master's and bachelor's degree. The reason to exclude uneducated rural residents from this study was that, during the pilot study, it was ascertained that uneducated respondents were hesitant to respond the questions. We inferred that it was because of lack of knowledge and understanding of the significance and purpose of this study. A simple random sampling method was adopted to choose the sample. Overall, 500 finalized questionnaires were self-distributed to target respondents, and the goal of the study as well as the questionnaire was explained. The sample was obtained from different geographical regions, such as Khyber PakhtoonKhwa, Punjab, Sindh, Balochistan, and Gilgit-Baltistan. Demographic characteristic of the sample is shown in Table 2. One month was given for the rural respondents to fill out and return the questionnaire.

Table 2. Demographic characteristics of the sample.

\begin{tabular}{cccccccc}
\hline \multicolumn{9}{c}{ Gender } & \multicolumn{7}{c}{ Age } \\
\hline Region & Female & Male & $\mathbf{2 0 - 2 9}$ & $\mathbf{3 0 - 3 9}$ & $\mathbf{4 0 - 4 9}$ & $\mathbf{2 5 0}$ & Total \\
\hline Khyber PakhtoonKhwa & 26 & 28 & 16 & 36 & 38 & 3 & 93 \\
Punjab & 63 & 82 & 16 & 45 & 38 & 7 & 106 \\
Sindh & 41 & 34 & 19 & 26 & 28 & 2 & 75 \\
Balochistan & 30 & 33 & 12 & 29 & 16 & 6 & 63 \\
Gilgit-Baltistan & 13 & 16 & 8 & 7 & 13 & 1 & 29 \\
\hline Total & 173 & 193 & 71 & 143 & 133 & 19 & 366 \\
\hline
\end{tabular}

\subsection{Data Processing and Feedback of Questionnaire}

All collected data were checked and confirmed for their correctness. Data scrubbing was performed by testing the frequency, descriptive statistics and data entry. The scrubbed data were then examined to obtain an analysis of test reliability, frequency analysis, descriptive statistical analysis, $t$-test, and ANOVA. Data processing was executed by statistical methods SPSS version 24.00 for MacBook.

Altogether, 500 questionnaires were handed, and a total of 366 completed questionnaire were received, representing an effective response rate of $73 \%$, which is considered excellent [68]. A total of $46.7 \%$ and $53.3 \%$ of the respondents hold a master's and bachelor's degree, respectively. For our analysis, we set occupation into four mutually exclusive groups: $22.1 \%$ employed (Group A), 14.5\% businessman (Group B), 32.2\% students (Group C), and 31.1\% unemployed (Group D). Moreover, all respondents were educated, and the four groups were categorized according to gender (Female, Male). The $47.3 \%$ female was suggested as Category 1 respondents, and the $52.7 \%$ male was named as Category 2 respondents. 


\subsection{Data Reliability}

Data reliability considers data source and requires knowledge of the respondent's understanding and the completed questionnaire [69]. The data reliability of the survey is verified using Cronbach's alpha $(\alpha)$ and the computing tool SPSS, which returned value 0.861 ; therefore, the value of the questionnaire survey revealed satisfactory reliability. Acceptable $\alpha$ value is greater than 0.7 , while the closer $\alpha$ is to +1 , the more reliable the test is [70]. The respondents hold sound knowledge and familiarity of community problems and judge the community challenges on the basis of their own experience during public construction project delays, which is the reason behind this satisfactory set of reliable data.

\section{Data Analysis}

This research aims to demonstrate and reveal the factors that contribute in influencing the rural community sustainable life during the public infrastructure project delays. The community influencing factors are identified from the literature, and each factor is evaluated independently.

\subsection{Analysis of Survey Data}

The primary data obtained from 366 respondents are analyzed from the perspective of rural community residents. We computed the mean score (MS), and standard deviation (SD) of each factor to demonstrate its level of importance, and the ranked factors are shown in Table 3. If two or more factors happened to have the same MS, we considered the one with lower SD to be more important [71,72]. The MS, SD, and ranking of the related economic and social factors are shown in Table 3.

Table 3. Mean score, standard deviation, and ranking for each factor.

\begin{tabular}{|c|c|c|c|c|}
\hline Influencing Factors & MS & SD & Rank & Overall Ranking \\
\hline \multicolumn{5}{|c|}{ Economic-Related Factors } \\
\hline High transportation costs (ECF_1) & 4.20 & 0.790 & 2 & 3 \\
\hline More expenditures on education (ECF_3) & 4.15 & 0.793 & 3 & 5 \\
\hline Limit the use of local market to the sale of their produces (ECF_4) & 3.97 & 0.885 & 8 & 15 \\
\hline Decreases the income earning (ECF_5) & 3.89 & 0.920 & 10 & 22 \\
\hline Hindrance to business growth (ECF_6) & 3.99 & 0.916 & 7 & 14 \\
\hline Increases the price of consumer goods (ECF_9) & 4.25 & 0.751 & 1 & 2 \\
\hline Obstruct the business opportunities (ECF_10) & 3.93 & 0.873 & 9 & 19 \\
\hline Increases healthcare expenditures (ECF_11) & 4.09 & 0.883 & 5 & 8 \\
\hline Decreases in economic growth (ECF_12) & 3.86 & 0.923 & 11 & 23 \\
\hline Impacts on local market development (ECF_13) & 4.06 & 0.897 & 6 & 10 \\
\hline Impact the living standard (SOF_4) & 4.08 & 0.838 & 4 & 9 \\
\hline Barriers to primary healthcare access (SOF_5) & 4.15 & 0.973 & 3 & 5 \\
\hline Lack of educational opportunities (SOF_6) & 4.16 & 0.898 & 2 & 4 \\
\hline Increase in travel time (SOF_7) & 4.04 & 0.913 & 6 & 12 \\
\hline Increases community healthcare issues (SOF_8) & 4.06 & 0.857 & 5 & 10 \\
\hline Difficulties in-time access to hospitals and educational institutions (SOF_9) & 3.90 & 1.028 & 11 & 20 \\
\hline Hurdles to higher academic achievement (SOF_10) & 3.94 & 1.027 & 9 & 17 \\
\hline Unbalanced educational development (SOF_11) & 3.94 & 0.892 & 9 & 17 \\
\hline Decrease in school enrollment rates (Primary school-age children) (SOF_12) & 3.61 & 1.053 & 13 & 26 \\
\hline Suffer adult basic education (SOF_13) & 3.90 & 0.938 & 11 & 20 \\
\hline
\end{tabular}

\subsection{Economic-Related Factors}

Table 3 shows the mean score, standard deviation, and ranking of each factor under the economic-related factors from the rural community residents' view. According to the economic-related factors ranking, the six most important factors are: Increases the price of consumer goods $(\mathrm{MS}=4.25, \mathrm{SD}=0.751)$, High transportation costs $(\mathrm{MS}=4.20, \mathrm{SD}=0.790)$, More expenditures on education (MS $=4.15, \mathrm{SD}=0.793)$, Increase costs of consumption and production of goods and services 
(MS $=4.10, S D=0.797)$, Increases healthcare expenditures $(\mathrm{MS}=4.09, \mathrm{SD}=0.883)$, and Impacts on local market development (MS = 4.06, $\mathrm{SD}=0.897$ ). In Table 3, MS ranges from 4.25 to 3.65 .

\subsection{Social-Related Factors}

Under the social-related factor, 13 main factors are documented, and Table 3 shows the top six affecting factors. The MS, SD, and ranking of each factor under in this group from the community residents' views are: Problems faced while travelling $(\mathrm{MS}=4.28, \mathrm{SD}=0.791)$, Lack of educational opportunities ( $\mathrm{MS}=4.16, \mathrm{SD}=0.898$ ), Barriers to primary healthcare access (MS $=4.15, \mathrm{SD}=0.973$ ), Impact the living standard ( $\mathrm{MS}=4.08, \mathrm{SD}=0.838$ ), Increases community healthcare issues $(\mathrm{MS}=4.06, \mathrm{SD}=0.857)$, and Increase in travel time ( $\mathrm{MS}=4.04, \mathrm{SD}=0.913)$. According to the ranking of this group factors, the MS ranges from 4.28 to 3.61 .

\subsection{Overall Ranking}

The MS, SD, and ranking of 26 investigated influencing factors during public infrastructure project delays from the rural community residents' view are shown in Table 3. Top six community influencing factors are: Problems faced while traveling (MS $=4.28, \mathrm{SD}=0.791$ ), Increases the price of consumer goods (MS = 4.25, $\mathrm{SD}=0.751)$, High transportation costs $(\mathrm{MS}=4.20, \mathrm{SD}=0.790)$, Lack of educational opportunities ( $\mathrm{MS}=4.16, \mathrm{SD}=0.898$ ), More expenditures on education $(\mathrm{MS}=4.15, \mathrm{SD}=0.793$ ) and Barriers to primary healthcare access ( $\mathrm{MS}=4.15, \mathrm{SD}=0.973$ ). The result shows that the top six influencing factors are related to both economic and social related factors. In Table 3, the MS ranges from 4.25 to 3.65 and 4.28 to 3.61 for economic and social-related factors, respectively, which are similar, thus it is inferred that the respondents have a moderately noticeable concentration on those factors in common.

\section{5. $t$-Test}

The $t$-test is used to ascertain if there is a significant difference between the mean scores of two independent groups [68]. The significant value is set to be 0.05 . The significance value is the main value that is used to evaluate the difference between two independent groups about their opinions of the importance of a particular variable. If the significant value is greater than 0.05 , the two groups can be preserved as significantly the same, and no significant difference exists; otherwise, the two groups are not consistent with their perceptions. As there are distinct awareness and experience between the two categories on infrastructure project delays affect the rural community needs and expectations, the $t$-test is used in this study to check the opinion of the significance of individual influencing factor whether the rural respondents in Category 1 and Category 2 have significant differences in the views. Table 4 illustrates the results of the $t$-test performed, and compares the MS, SD, and the significant value of each factor.

Table 4 shows that the rural respondents' views among the two groups, i.e., Category 1 and Category 2, are significantly consistent in weighing the significance of rural community influencing factors during the construction project delays, apart from the significant disparity of opinion of some factors: two economic-related factors, i.e. "Hindrance to business growth" and "Obstruct the business opportunities". Category 2 respondents give more importance on the significance of these two factors than Category 1 respondents. This is because most Category 2 respondents have expertise in business and these two factors are related to business extension directly. In Category 2, 14.5\% respondents are directly related to business activities, and import and export goods from and to the local market, and thus Category 2 respondents judge these factors more critical in impacting the development of the community than Category 1 respondents. Local business is essential to the local economy because they increase multiplier effects by increasing the external demand for products [73]. It is notable that both of these influencing factors need good knowledge to assess the impact on residents, and Category 2 respondents have enough knowledge to interpret such consequence. 
In particular, Category 2 respondents tend to give extra importance to the significance of all influencing factors compared to Category 1 respondents. Both Category 1 and Category 2 respondents believe that economic-related factors and social-related factors influence the rural community needs and face troubles during construction project delays in Pakistan.

Table 4. Independent sample $t$-test results for Category 1 and Category 2.

\begin{tabular}{|c|c|c|c|c|c|c|c|c|}
\hline \multirow{2}{*}{ Code } & \multicolumn{2}{|c|}{ Category 1} & \multicolumn{2}{|c|}{ Category 2} & \multicolumn{2}{|c|}{ Total } & \multirow{2}{*}{ Sig. } & \multirow{2}{*}{$\begin{array}{c}\text { Sig. Diff } \\
(\mathrm{Y} / \mathrm{N})\end{array}$} \\
\hline & MS & SD & MS & SD & MS & SD & & \\
\hline ECF_1 & 4.14 & 0.831 & 4.25 & 0.750 & 4.20 & 0.790 & 0.18 & $\mathrm{~N}$ \\
\hline ECF_2 & 4.07 & 0.860 & 4.13 & 0.738 & 4.10 & 0.797 & 0.43 & $\mathrm{~N}$ \\
\hline ECF_3 & 4.16 & 0.819 & 4.15 & 0.770 & 4.15 & 0.793 & 0.84 & $\mathrm{~N}$ \\
\hline ECF_4 & 3.91 & 0.993 & 4.03 & 0.773 & 3.97 & 0.885 & 0.22 & $\mathrm{~N}$ \\
\hline ECF_5 & 3.82 & 0.945 & 3.96 & 0.895 & 3.89 & 0.920 & 0.15 & $\mathrm{~N}$ \\
\hline ECF_6 & 3.88 & 0.993 & 4.08 & 0.831 & 3.99 & 0.916 & 0.04 & $\mathrm{Y}$ \\
\hline ECF_7 & 3.61 & 1.043 & 3.69 & 0.961 & 3.65 & 1.000 & 0.47 & $\mathrm{~N}$ \\
\hline ECF_8 & 3.68 & 0.970 & 3.79 & 0.891 & 3.73 & 0.929 & 0.25 & $\mathrm{~N}$ \\
\hline ECF_9 & 4.24 & 0.746 & 4.25 & 0.757 & 4.25 & 0.751 & 0.94 & $\mathrm{~N}$ \\
\hline ECF_10 & 3.82 & 0.920 & 4.04 & 0.819 & 3.93 & 0.873 & 0.02 & $\mathrm{Y}$ \\
\hline ECF_11 & 4.03 & 0.955 & 4.15 & 0.812 & 4.09 & 0.883 & 0.19 & $\mathrm{~N}$ \\
\hline ECF_12 & 3.82 & 0.983 & 3.91 & 0.867 & 3.86 & 0.923 & 0.34 & $\mathrm{~N}$ \\
\hline ECF_13 & 4.09 & 0.884 & 4.04 & 0.909 & 4.06 & 0.897 & 0.55 & $\mathrm{~N}$ \\
\hline SOF_1 & 3.98 & 0.946 & 4.07 & 0.863 & 4.03 & 0.903 & 0.31 & $\mathrm{~N}$ \\
\hline SOF_2 & 4.23 & 0.845 & 4.33 & 0.739 & 4.28 & 0.791 & 0.23 & $\mathrm{~N}$ \\
\hline SOF_3 & 3.88 & 0.966 & 4.02 & 0.857 & 3.95 & 0.911 & 0.15 & $\mathrm{~N}$ \\
\hline SOF_4 & 4.08 & 0.856 & 4.09 & 0.824 & 4.08 & 0.838 & 0.84 & $\mathrm{~N}$ \\
\hline SOF_5 & 4.08 & 0.889 & 4.22 & 1.039 & 4.15 & 0.973 & 0.15 & $\mathrm{~N}$ \\
\hline SOF_6 & 4.12 & 0.844 & 4.19 & 0.945 & 4.16 & 0.898 & 0.49 & $\mathrm{~N}$ \\
\hline SOF_7 & 3.96 & 0.936 & 4.10 & 0.890 & 4.04 & 0.913 & 0.13 & $\mathrm{~N}$ \\
\hline SOF_8 & 4.06 & 0.881 & 4.06 & 0.837 & 4.06 & 0.857 & 0.99 & $\mathrm{~N}$ \\
\hline SOF_9 & 3.80 & 1.093 & 3.98 & 0.963 & 3.90 & 1.028 & 0.10 & $\mathrm{~N}$ \\
\hline SOF_10 & 3.97 & 0.967 & 3.91 & 1.079 & 3.94 & 1.027 & 0.58 & $\mathrm{~N}$ \\
\hline SOF_11 & 3.87 & 0.946 & 4.01 & 0.839 & 3.94 & 0.892 & 0.14 & $\mathrm{~N}$ \\
\hline SOF_12 & 3.54 & 1.048 & 3.67 & 1.057 & 3.61 & 1.053 & 0.24 & $\mathrm{~N}$ \\
\hline SOF_13 & 3.88 & 0.891 & 3.92 & 0.981 & 3.90 & 0.938 & 0.70 & $\mathrm{~N}$ \\
\hline
\end{tabular}

\subsection{One-Way ANOVA}

ANOVA is conducting to test whether perception differences exist among more than two groups [74]. We carried out a one-way ANOVA to test for significant differences in the respondents' views in responses from the four groups for each influencing factor. Moreover, ANOVA was used to inspect whether the opinions of the four different groups of respondents are consistent for each of the influencing factor. If a significant value is less than 0.05 , it recommends that a high degree of difference of opinion exists among the group [7]; contrarily, if a significant value is greater than 0.05 , then there are no differences in opinion among the groups. The respondents were divided into four different groups: employed, businessman, student and unemployed. The values are computed by SPSS, and the results are illustrated in Table 5.

It is clear from the ANOVA test result in Table 5 that all four group respondents are consistent and there are no differences found in perception among perception of respondents, except "Hindrance to business growth" (sig. = 0.019), and "Increase in travel time" (sig. $=0.004)$. The differences of perception exist among the four groups of respondents on the significance of the two factors. The MS noticed by Group C (student respondents), and Group D (unemployed respondents) on influencing factors are lower than Group A and Group B respondents. This is because Group A and Group $\mathrm{B}$ respondents have better knowledge about business. It is important that both these factors need business experience and frequently travel to urban areas to assess the impact on residents. This may indicate that the businessman faces challenges to import and export the goods (mostly perishable and 
consumer goods) to and from the market due to delay in construction. Sometimes the businessman cannot export the seasonal goods to the market due to stoppage or delay in construction. Transport infrastructure plays a vital role in improving the local economy [48]. Similarly, for the factor "increase in travel time", Group B respondents ranked it more important, whereas it has less importance to Group C.

In general, all respondents are substantially consistent in judging the significance of community influencing factors during delays in public projects.

Table 5. One-way ANOVA test results.

\begin{tabular}{|c|c|c|c|c|c|c|c|c|}
\hline & \multicolumn{4}{|c|}{ Mean Score } & \multicolumn{2}{|c|}{ Total } & \multirow{2}{*}{ Sig. Value } & \multirow{2}{*}{$\begin{array}{c}\text { Sig. Diff } \\
(\mathrm{Y} / \mathrm{N})\end{array}$} \\
\hline & Group A & Group B & Group C & Group D & MS & SD & & \\
\hline ECF_1 & 4.28 & 4.25 & 4.14 & 4.18 & 4.20 & 0.790 & 0.579 & $\mathrm{~N}$ \\
\hline ECF_2 & 4.17 & 4.13 & 4.10 & 4.04 & 4.10 & 0.797 & 0.726 & $\mathrm{~N}$ \\
\hline ECF_3 & 4.20 & 4.21 & 4.04 & 4.21 & 4.15 & 0.793 & 0.334 & $\mathrm{~N}$ \\
\hline ECF_4 & 4.09 & 3.91 & 3.84 & 4.06 & 3.97 & 0.885 & 0.139 & $\mathrm{~N}$ \\
\hline ECF_5 & 3.98 & 3.92 & 3.88 & 3.83 & 3.89 & 0.920 & 0.752 & $\mathrm{~N}$ \\
\hline ECF_6 & 4.16 & 4.19 & 3.81 & 3.96 & 3.99 & 0.916 & 0.019 & $\mathrm{Y}$ \\
\hline ECF_7 & 3.83 & 3.57 & 3.52 & 3.71 & 3.65 & 1.000 & 0.143 & $\mathrm{~N}$ \\
\hline ECF_8 & 3.89 & 3.75 & 3.57 & 3.79 & 3.73 & 0.929 & 0.091 & $\mathrm{~N}$ \\
\hline ECF_9 & 4.30 & 4.30 & 4.18 & 4.25 & 4.25 & 0.751 & 0.652 & $\mathrm{~N}$ \\
\hline ECF_10 & 4.07 & 4.02 & 3.86 & 3.87 & 3.93 & 0.873 & 0.265 & $\mathrm{~N}$ \\
\hline ECF_11 & 4.22 & 4.17 & 4.04 & 4.02 & 4.09 & 0.883 & 0.341 & $\mathrm{~N}$ \\
\hline ECF_12 & 3.98 & 4.09 & 3.72 & 3.82 & 3.86 & 0.923 & 0.056 & $\mathrm{~N}$ \\
\hline ECF_13 & 4.01 & 4.04 & 4.04 & 4.13 & 4.06 & 0.897 & 0.795 & $\mathrm{~N}$ \\
\hline SOF_1 & 3.99 & 4.08 & 4.02 & 4.04 & 4.03 & 0.903 & 0.949 & $\mathrm{~N}$ \\
\hline SOF_2 & 4.25 & 4.36 & 4.31 & 4.25 & 4.28 & 0.791 & 0.783 & $\mathrm{~N}$ \\
\hline SOF_3 & 4.07 & 3.92 & 3.83 & 4.00 & 3.95 & 0.911 & 0.271 & $\mathrm{~N}$ \\
\hline SOF_4 & 4.21 & 3.98 & 4.05 & 4.08 & 4.08 & 0.838 & 0.423 & $\mathrm{~N}$ \\
\hline SOF_5 & 4.14 & 4.57 & 3.98 & 4.15 & 4.15 & 0.973 & 0.004 & $\mathrm{Y}$ \\
\hline SOF_6 & 4.30 & 4.13 & 4.12 & 4.11 & 4.16 & 0.898 & 0.462 & $\mathrm{~N}$ \\
\hline SOF_7 & 3.98 & 4.13 & 3.99 & 4.08 & 4.04 & 0.913 & 0.690 & $\mathrm{~N}$ \\
\hline SOF_8 & 4.14 & 4.09 & 3.92 & 4.12 & 4.06 & 0.857 & 0.230 & $\mathrm{~N}$ \\
\hline SOF_9 & 4.01 & 3.96 & 3.71 & 3.97 & 3.90 & 1.028 & 0.127 & $\mathrm{~N}$ \\
\hline SOF_10 & 3.80 & 3.94 & 3.84 & 4.14 & 3.94 & 1.027 & 0.073 & $\mathrm{~N}$ \\
\hline SOF_11 & 4.02 & 3.96 & 3.88 & 3.93 & 3.94 & 0.892 & 0.734 & $\mathrm{~N}$ \\
\hline SOF_12 & 3.72 & 3.72 & 3.49 & 3.61 & 3.61 & 1.053 & 0.415 & $\mathrm{~N}$ \\
\hline SOF_13 & 3.84 & 3.92 & 3.76 & 4.07 & 3.90 & 0.938 & 0.083 & $\mathrm{~N}$ \\
\hline
\end{tabular}

\section{Discussion}

From the analysis, it can be concluded that all 26 economic and social factors influence the community needs and expectations during project delays. These findings are beneficial for the government to improve the plans and policies and to monitor the community need (benefits) during the project delays. From the overall ranking of economic and social related factors, the survey signified that 6 out of 26 factors are considered the most important influencing factors, thus are discussed below.

\subsection{Problems Faced While Traveling (SOF_2)}

The overall ranking shows that the respondents ranked "Problems faced while traveling" as the most important factor affecting the rural community. Rural residents reside near urban areas and travel to jobs, academic institutions, and hospitals. Market access is also more demanding because of job market competition. Mobility levels in rural regions are usually higher than in urban areas [75], and rural residents travel 59\% more miles per day than their urban counterparts [76]. Rural residents travel to or from urban areas through roads, which are the main pillar between rural and urban areas. Rural residents face mobility issue because of poor and delayed infrastructure construction. This challenged the mobility of a society in general and the working class specifically. Businesses, academic institutions, and job-holders' daily routine and their performance in the relevant organization are indirectly hampered because of poor conditions 
and delayed projects (roads). Student focus on study, access to hospitals, working-class efficiency in offices, and businessmen's potential in the dynamic competitive environment are underutilized because of public project postponement. A delay in road projects means challenging travel and uncertain travel times for people. Thus, rural residents face problems during construction project delays, and the government should take corrective plans to overcome these problems.

\subsection{Increases the Price of Consumer Goods (ECF_9)}

The respondents perceived the second most important influencing factor as "Increases the price of consumer goods". Rural economies interconnect with and mainly depend on urban markets [77,78]. Transportation plays a vital role in the socio-economic development of rural economies $[79,80]$ and the majority of the consumer goods are transported from urban markets. For instance, when a road project is delayed, it hampers easy access to the urban market. This compels the local businessman to use alternate transport, which is not only costly for them but also time-consuming [81]. Thus, there is an increase in the price of consumer goods and major food commodities. The high transaction and transport costs escalate commodity prices, which are transferred onto consumers. Increases in consumer goods prices have dampened economic growth, and rural residents' spending and income are affected as well as saving rates dropped sharply. Poor rural residents usually sustain this pressure to curtail down their spending on consumer goods. Thus, government should develop an appropriate policy for rural residents on increased prices of goods during project delays, and also ensure that projects are completed on time, and within the quality.

\subsection{High Transportation Cost (ECF_1)}

This factor is the third most important factor ranked by the respondents in the overall ranking. Rural communities are directly linked to urban areas through the roads, and public transportation helps rural residents' mobility to the markets, business activities, educational institutions, hospitals, and workplaces. For instance, better condition of roads provide not only access to the markets, hospitals, and educational institutions, but also comfortable travel and reduce transportation cost of rural residents [48]. Project delays limit the rural businessman's access to the urban market to transport commercial goods. It also increases the cost for the competitive market because of increase of logistic cost and freight rates. In some cases, rural businessman uses old means of transportation, e.g., horses and mules, to transport their goods, which may incur high transportation cost. Similarly, delay in road projects may hamper mobility of agriculture goods between field and market. The higher transportation cost increases the cost of agriculture, for instance, bringing fertilizers and agriculture products from markets and selling of agriculture goods in the market. In addition, poor physical infrastructure also has a severe impact on producers' prices, as inadequate roads normally cause high transport costs [77].

On the other hand, another purpose of government is to facilitate the rural community with basic and quality education. When the educational institution's project delays, it limits the access of rural population to the urban educational institutions. The additional expenditure to manage daily pick up and drop off van service for children results in a rural community paying high transportation cost for acquiring children's education. Furthermore, when a healthcare project is delayed in rural areas, the rural community confront challenges to travel frequently to urban healthcare centers for medical facilities [56]. The long distance and frequent visits enhance the transportation cost burden to the poor residents.

\subsection{Lack of Educational Opportunities (SOF_6)}

One of the important factor identified from the study is "Lack of educational opportunities", which is the fourth influencing factor identified. Educational institutions help to produce knowledge, build people's skills, shape human capital, regulate and ration social status, and mediate opportunity sets accessible to individuals [82]. Moreover, the local educational institutions provide primary and 
secondary education, giving hope to rural residents to get a quality education that increases their future employment opportunities. The significance of education is to promote individual inhabitant as well as rural development and agriculture improvement. The rural community relies on government educational institutions. If the government is unable to provide educational opportunities due to construction delays, then the poor rural residents cannot afford (school fees, transportation costs, etc.) to enroll their children in urban educational institutions. The long distance to primary school has a negative impact on the school dropout rate and educational attainment in rural areas [83,84]. Thus, children's education will suffer, and it may impair children's cognitive abilities in rural areas.

\subsection{More Expenditures on Education (ECF_3)}

The fifth significant influencing factor is "More expenditures on education". It is acknowledged that expenditure on education is one of the key factors for sustainable development. The government, because of financial constraints, provides only basic education facilities in rural communities [82,85]. However, when educational institution projects are delayed in rural areas, the rural residents who can afford to reluctantly enroll their children in urban educational institutions, which may incur greater expenditures and transaction cost. This can increase the transportation cost as addressed above and reduce the enrollment in basic education of the rural children. Thus, the expenditure on children's education is higher for rural residents as compared to their urban counterparts. Thus, the government should focus more on children's education in rural communities and also make sure to complete such projects on time.

\subsection{Barriers to Primary Health Care Access (SOF_5)}

The sixth vital affecting factor is "Barriers to primary healthcare access", as rural dispensaries or small bedded hospitals (30-50) are the key places for satisfying health needs of rural communes. Lack of access to healthcare center is a major healthcare problem for rural residents. When healthcare projects are delayed, rural residents have to access the urban hospitals, which are challenging and costly. When healthcare projects are delayed for any reason, rural residents face a problem to access outpatient, inpatient, emergency and diagnostic care. The lack of health services adversely affects the rural residents' health and their quality of life. The rural populations confront special challenges in the provision of healthcare services, including scarcities of primary healthcare providers in rural areas [86]. For rural inhabitants to have necessary healthcare access, healthcare projects must be completed within defined time, quality and availability of sufficient amenities. Otherwise, rural community will be confronted with severe economic and social consequences of such project delays.

All of the above-addressed factors were discussed with five community leaders to validate the significance of these factors. The suggestions by the community leaders support this result. In general, however, project delays impact on the availability of services and needs in the project communes. The results show that the construction project delays directly affect the community's needs, expectations, and sustainable living.

\section{Conclusions}

The development of a country significantly depends on the conditions of its infrastructure. An appropriate infrastructure may lead to economic growth and social well-being of the population. This study explored the perception of rural residents' of socio-economic difficulties and challenges faced by residents during delays in construction projects. In development policies, the government of Pakistan allocates sufficient budget for the infrastructure development and makes reliable plans for implementation. Delays in public construction projects are a common phenomenon. Sustainable rural development can be significantly influenced by the delays in construction projects. The influence of project delays from the owner and contractor perspective is well represented in the literature, but the community suffering from such project delays was ignored. However, in this study, the challenges faced by rural residents during project delays was thoroughly discussed, and it was found that rural 
residents were confronted with difficulties and suffer from these delays. The project can only succeed if the needs and expectations of residents are taken into account [87]. The research results showed that the delay in construction projects in rural areas ultimately jeopardize its economic growth, social life, and sustainability. In assessing the likely delays of rural infrastructure projects, the government should consider the impact on the rural community.

This study identified problems related to rural residents during delays in construction projects. A compiled list of 26 influencing factors was identified from the literature and subjected to quantitative assessment in a questionnaire survey for verification, and the most significant influencing factors were ranked. Data were collected and analyzed using mean scores, standard deviation, $t$-test, and ANOVA in SPSS version 24.0. Out of 26 influencing factors incorporated into the questionnaire, the top six most important factors were highlighted and discussed in detail: Problems faced while traveling, Increases the price of consumer goods, High transportation costs, Lack of educational opportunities, More expenditures on education, and Barriers to primary healthcare access. The results showed that rural communities confronted severe challenges because of the delays in construction projects. In general, the result of this study found through $t$-test and ANOVA analysis that all respondents were substantially consistent in judging the significance of all influencing factors.

The findings provide practitioners and decision makers with a clear understanding of the rural problems during construction delays. A practical contribution of these findings is to realize the infrastructure project delay implication on rural communities. We suggest that policymakers and public project officials concentrate not only on the planning and execution phase but also make sure to complete the project on time because it incurs economic and social cost on the rural communities.

Acknowledgments: This research work was supported by the National Natural Science Foundation of China under Grant No. 71372085. Furthermore, the worthy comments and suggestions from the editor and all the reviewers are extremely appreciated.

Author Contributions: Shahid Hussain and Zhu FangWei formulated the research design and organized most of the data. The analysis was conducted by Shahid Hussain, Zaigham Ali, and Xiaohang Xu. Shahid Hussain (with 12 team members) and Zaigham Ali (with eight team members) collected the data from Pakistan. Shahid Hussain wrote the manuscript.

Conflicts of Interest: The authors declare no conflict of interest.

\section{References}

1. Cellini, S.R.; Ferreira, F.; Rothstein, J. The Value of School Facility Investments: Evidence from a Dynamic Regression Discontinuity Design. Q. J. Econ. 2010, 125, 215-261. [CrossRef]

2. Fan, S.; Hazell, P.; Thorat, S. Government Spending, Growth and Poverty in Rural India. Am. J. Agric. Econ 2000, 82, 1038-1051. [CrossRef]

3. Yates, A. A Framework for Studying Mortality Arising from Critical Infrastructure Loss. Int. J. Crit. Infrastruct. Prot. 2014, 7, 100-111. [CrossRef]

4. Alzahrani, J.I.; Emsley, M.W. The Impact of Contractors' Attributes on Construction Project Success: A Post Construction Evaluation. Int. J. Proj. Manag. 2013, 31, 313-322. [CrossRef]

5. Collins, A.; Baccarini, D. Project Success-A Survey. J. Constr. Res. 2004, 5, 211-231. [CrossRef]

6. Mahamid, I.; Bruland, A.; Dmaidi, N. Causes of Delay in Road Construction Projects. J. Manag. Eng. 2012, 28, 300-310. [CrossRef]

7. Shen, L.; Asce, M.; Lu, W.; Peng, Y.; Jiang, S. Critical Assessment Indicators for Measuring Benefits of Rural Infrastructure Investment in China. J. Infrastruct. Syst. 2011, 17, 176-183. [CrossRef]

8. Pal, S. Public Infrastructure, Location of Private Schools and Primary School Attainment in an Emerging Economy. Econ. Educ. Rev. 2010, 29, 783-794. [CrossRef]

9. Queiroz, C.; Gautam, S. Road Infrastructure and Economic Development: Some Diagnostic Indicators; World Bank Publications: Washington, DC, USA, 1992; Volume 921.

10. Pearce, D.; Barbier, E.; Markandya, A. Sustainable Development: Economics and Environment in the Third World; Routledge: Abingdon, UK, 2013. 
11. Scott, M.; Murray, M. Housing Rural Communities: Connecting Rural Dwellings to Rural Development in Ireland. Hous. Stud. 2009, 24, 755-774. [CrossRef]

12. Akogbe, R.-K.T.M.; Feng, X.; Zhou, J. Importance and Ranking Evaluation of Delay Factors for Development Construction Projects in Benin. KSCE J. Civ. Eng. 2013, 17, 1213-1222. [CrossRef]

13. Kaliba, C.; Muya, M.; Mumba, K. Cost Escalation and Schedule Delays in Road Construction Projects in Zambia. Int. J. Proj. Manag. 2009, 27, 522-531. [CrossRef]

14. Sahoo, P.; Dash, R.K. Economic Growth in South Asia: Role of Infrastructure. J. Int. Trade Econ. Dev. 2012, 21, 217-252. [CrossRef]

15. Aschauer, D.A. Why Is Infrastructure Important? Transp. Res. Board 1990, 21-68.

16. Sahoo, P.; Dash, R.K.; Nataraj, G. Infrastructure Development and Economic Growth in China. Inst. Dev. Econ. 2010, 10, 1-39. Available online: http:/ / www.ide.go.jp/English/Publish/Download/Dp/261.html (accessed on 16 November 2017).

17. Calderón, C.; Servén, L. Infrastructure and Economic Development in Sub-Saharan Africa. J. Afr. Econ. 2010, 19, 1-70. [CrossRef]

18. Ha, O.; Park, D.; Lee, K.; Won, J. Evaluation Criteria for Road Networks in Residential Areas. KSCE J. Civ. Eng. 2011, 15, 1273-1284. [CrossRef]

19. Oraboune, S. Infrastructure (Rural Road) Development and Poverty Alleviation in Lao PDR. Inst. Dev. Econ. 2008, 4, 1-74. Available online: http:/ / www.ide.go.jp/English/Publish/Download/Dp/151.html (accessed on 16 November 2017).

20. Minten, B.; Kyle, S. The Effect of Distance and Road Quality on Food Collection, Marketing Margins, and Traders' Wages: Evidence from the Former Zaire. J. Dev. Econ. 1999, 60, 467-495. [CrossRef]

21. Antle, J.M. Human Capital, Infrastructure, and the Productivity of Indian Rice Farmers. J. Dev. Econ. 1984, 14, 163-181. [CrossRef]

22. Qin, Y.; Zhang, X. The Road to Specialization in Agricultural Production: Evidence from Rural China. World Dev. 2016, 77, 1-16. [CrossRef]

23. Modinpuroju, A.; Prasad, C.S.; Chandra, M. Facility-Based Planning Methodology for Rural Roads Using Spatial Techniques. Innov. Infrastruct. Solut. 2016, 1, 41. [CrossRef]

24. Tian, Y.; Li, Y.; Chen, X. Evaluating the Impact of Rural Road Investment Projects on Household Welfare in Rural Area: Evidence from Fujian Province. Int. Conf. Transp. Eng. 2009, 1, 3602-3608.

25. Doeksen, G.A.; Loewen, R.A.; Strawn, D.A. A Rural Hospital's Impact on a Community's Economic Health. J. Rural Health 1990, 6, 53-64. [CrossRef] [PubMed]

26. Vaughan, M.; Hilsenrath, P.; Ludke, R.L. The Contribution of Hospitals to Local Economy: A Case Study in Lowa and Illinois. Health Care Manag. Rev. 1994, 19, 34-40. [CrossRef]

27. DeYoung, A.J. The Status of American Rural Education Research: An Integrated Review and Commentary. Rev. Educ. Res. 1987, 57, 123-148. [CrossRef]

28. Dewees, S.; Velázquez, J.A. Community Development in Rural Texas: A Case Study of Balmorhea Public Schools. Community Dev. Soc. J. 2000, 31, 216-232. [CrossRef]

29. Minta, B. Towards Economic Development of the Chicano: Alternative Strategies and Their Implications. Southwest Econ. Soc. 1975, 1, 1-29.

30. Gündüz, M.; Nielsen, Y.; Özdemir, M. Quantification of Delay Factors Using the Relative Importance Index Method for Construction Projects in Turkey. J. Manag. Eng. 2013, 29, 133-139. [CrossRef]

31. Hwang, B.; Zhao, X.; Yi, S. Identifying the Critical Factors Affecting Schedule Performance of Public Housing Projects. Habitat Int. 2013, 38, 214-221. [CrossRef]

32. Olawale, Y.; Sun, M. PCIM: A Project Control and Inhibiting-Factors Management Model. J. Manag. Eng. 2013, 29, 60-70. [CrossRef]

33. Hamzah, N.; Khoiry, M.A.; Arshad, I.; Tawil, N.M.; Che Ani, A.I. Cause of Construction Delay-Theoretical Framework. Procedia Eng. 2011, 20, 490-495. [CrossRef]

34. Kadir, M.R.A.; Lee, W.P.; Jaafar, M.S.; Sapuan, S.M.; Ali, A. Factors Affecting Construction Labour Productivity for Malaysian Residential Projects. Struct. Surv. 2005, 23, 42-54. [CrossRef]

35. Abdul-Rahman, H.; Berawi, M.A.; Berawi, A.R.; Mohamed, O.; Othman, M.; Yahya, I.A. Delay Mitigation in the Malaysian Construction Industry. J. Constr. Eng. Manag. 2006, 132, 125-133. [CrossRef]

36. Assaf, S.A.; Al-Hejji, S. Causes of Delay in Large Construction Projects. Int. J. Proj. Manag. 2006, 24, 349-357. [CrossRef] 
37. Odeyinka, H.A.; Yusif, A. The Causes and Effects of Construction Delays on Completion Cost of Housing Projects in Nigeria. J. Financ. Manag. Prop. Constr. 1997, 2, 31-44.

38. Doloi, H.; Sawhney, A.; Iyer, K.C.; Rentala, S. Analysing Factors Affecting Delays in Indian Construction Projects. Int. J. Proj. Manag. 2012, 30, 479-489. [CrossRef]

39. Faridi, A.; El-Sayegh, S. Significant Factors Causing Delay in the UAE Construction Industry. Constr. Manag. Econ. 2006, 24, 1167-1176. [CrossRef]

40. Larsen, J.K.; Shen, G.Q.; Lindhard, S.M.; Brunoe, T.D. Factors Affecting Schedule Delay, Cost Overrun, and Quality Level in Public Construction Projects. J. Manag. Eng. 2015. [CrossRef]

41. Odeh, A.M.; Battaineh, H.T. Causes of Construction Delay: Traditional Contracts. Int. J. Proj. Manag. 2002, 20,67-73. [CrossRef]

42. Manzoor Arain, F.; Sui Pheng, L. The Potential Effects of Variation Orders on Institutional Building Projects. Facilities 2005, 23, 496-510. [CrossRef]

43. Okkonen, L.; Lehtonen, O. Socio-Economic Impacts of Community Wind Power Projects in Northern Scotland. Renew. Energy 2016, 85, 826-833. [CrossRef]

44. Jordhus-Lier, D. Community Resistance to Megaprojects: The Case of the N2 Gateway Project in Joe Slovo Informal Settlement, Cape Town. Habitat Int. 2015, 45, 169-176. [CrossRef]

45. Mu, R.; van de Walle, D. Rural Roads and Local Market Development in Vietnam. J. Dev. Stud. 2009, 47, 709-734. [CrossRef]

46. Newhouse, D.; Beegle, K. The Effect of School Type on Academic Achievement: Evidence from Indonesia. J. Hum. Resour. 2006, 41, 529-557. [CrossRef]

47. Drèze, J.; Kingdon, G.G. School Participation in Rural India. Rev. Dev. Econ. 2001, 5, 1-24. [CrossRef]

48. Jacoby, H.G. Access to Markets and the Benefits of Rural Roads. Econ. J. 2000, 110, 713-737. [CrossRef]

49. Ogun, T.P. Infrastructure and Poverty Reduction: Implications for Urban Development in Nigeria. Urban Forum 2010, 21, 249-266. [CrossRef]

50. Gill, A.; Biger, N. Barriers to Small Business Growth in Canada. J. Small Bus. Enterp. Dev. 2012, 19, 656-668. [CrossRef]

51. Anríquez, G.; Stamoulis, K. Rural Development and Poverty Reduction: Is Agriculture Still the Key. Electron. J. Agric. Dev. Econ. 2007, 4, 5-46.

52. Obayelu, A.E.; Olarewaju, T.O.; Oyelami, N.L. Effect of Rural Infrastructure on Profitability and Productivity of Cassava-Based Farms in Odogbolu Local Government Area, Ogun State, Nigeria. J. Agric. Sci. 2014, 59, 187-200. [CrossRef]

53. Fakayode, S.B.; Omotesho, O.; Tsoho, A.B.; Ajayi, P.D. An Economic Survey of Rural Infrastructures and Agricultural Productivity Profiles in Nigeria. Eur. J. Soc. Sci. 2008, 7, 144-157.

54. Charlery, L.; Nielsen, M.; Meilby, H.; Smith-Hall, C. Effects of New Roads on Environmental Resource Use in the Central Himalaya. Sustainability 2016, 8, 363. [CrossRef]

55. Inoni, O.E.; Omotor, D.G. Effect of Road Infrastructure on Agricultural Output and Income of Rural Households in Delta State, Nigeria. Agric. Trop. Subtrop. 2009, 42, 90-97.

56. Kelly, J.; Dwyer, J.; Willis, E.; Pekarsky, B. Travelling to the City for Hospital Care: Access Factors in Country Aboriginal Patient Journeys. Aust. J. Rural Health 2014, 22, 109-113. [CrossRef] [PubMed]

57. Syed, S.T.; Gerber, B.S.; Sharp, L.K. Traveling towards Disease: Transportation Barriers to Health Care Access. J. Community Health 2013, 38, 976-993. [CrossRef] [PubMed]

58. Kumari, A.; Kumar Sharma, A. Infrastructure Financing and Development: A Bibliometric Review. Int. J. Crit. Infrastruct. Prot. 2017, 16, 49-65. [CrossRef]

59. Charlery, L.C.; Qaim, M.; Smith-Hall, C. Impact of Infrastructure on Rural Household Income and Inequality in Nepal. J. Dev. Eff. 2016, 8, 266-286. [CrossRef]

60. Surchev, P. Rural Areas-Problems and Opportunities for Development. Trakia J. Sci. 2010, 8, $234-239$.

61. Yılmaz, M.; Bakış, A. Sustainability in Construction Sector. Procedia Soc. Behav. Sci. 2015, 195, $2253-2262$. [CrossRef]

62. Joshi, B.K. Social Services Synegy: A Case Study from Uttrakhand Hill. Elixir Int. J. 2012, 53, 11937-11942.

63. Chan, L.; Hart, L.G.; Goodman, D.C. Geographic Access to Health Care for Rural Medicare Beneficiaries. J. Rural Health 2006, 22, 140-146. [CrossRef] [PubMed]

64. Bodenheimer, T.; Pham, H.H. Primary Care: Current Problems and Proposed Solutions. Health Aff. 2010, 29, 799-805. [CrossRef] [PubMed] 
65. Atchoarena, D.; Gasperini, L. Education for Rural Development: Towards New Policy Responses; International Institute for Educational Planning (IIEP) UNESCO: Paris, France, 2003.

66. Sherman, A. Falling by the Wayside: Children in Rural America; ERIC: Washington, DC, USA, 1992.

67. Han, Y.; Zhang, Y.; Yang, X. Analysis on the Differences of Pre-School Education Development in Western China from the Perspective of Balanced Urban and Rural Areas Development. Open J. Soc. Sci. 2016, 4, 115-121. [CrossRef]

68. Babbie, E. The Practice of Social Research, 11th ed.; Thomson Wadsworth: Nashville, TN, USA, 2007.

69. Oppenheim, A.N. Designing Attitude Statements \& Attitude Scaling. In Questionnaire Design, Interviewing and Attitude Measurement; Pinter Publishers: London, UK, 1992; pp. 174-209.

70. Gliem, J.A.; Gliem, R.R. Calculating, Interpreting, and Reporting Cronbach's Alpha Reliability Coefficient for Likert-Type Scales. Midwest Res. Pract. Conf. Adult Contin. Community Educ. 2003, 82-88. [CrossRef]

71. Wang, J.; Yuan, H. Factors Affecting Contractors' Risk Attitudes in Construction Projects: Case Study from China. Int. J. Proj. Manag. 2011, 29, 209-219. [CrossRef]

72. Lu, W.; Zhang, L.; Pan, J. Identification and Analyses of Hidden Transaction Costs in Project Dispute Resolutions. Int. J. Proj. Manag. 2015, 33, 711-718. [CrossRef]

73. Skuras, D.; Meccheri, N.; Moreira, M.B.; Rosell, J.; Stathopoulou, S. Business Growth and Development Trajectories in Lagging and Remote Areas of Southern Europe. Eur. Urban Reg. Stud. 2005, 12, 335-351. [CrossRef]

74. Kottegoda, N.T.; Rosso, R. Applied Statistics for Civil and Environmental Engineers; McGraw-Hill: New York, NY, USA, 1997.

75. Pucher, J.; Renne, J.L. Rural Mobility and Mode Choice: Evidence from the 2001 National Household Travel Survey. Transportation 2005, 32, 165-186. [CrossRef]

76. Probst, J.C.; Laditka, S.B.; Wang, J.-Y.; Johnson, A.O. Effects of Residence and Race on Burden of Travel for Care: Cross Sectional Analysis of the 2001 US National Household Travel Survey. BMC Health Serv. Res. 2007, 7, 40. [CrossRef] [PubMed]

77. Tacoli, C. The Links between Urban and Rural Development. Environ. Urban 2003, 15, 3-12. [CrossRef]

78. Ruttan, V.W. Integrated Rural Development Programs: A Skeptical Perspective. Int. Dev. Rev. 1975, 17, 9-16. [PubMed]

79. Chung, H. Some Socio-Economic Impacts of Toll Roads in Rural China. J. Transp. Geogr. 2002, 10, $145-156$. [CrossRef]

80. Asomani-Boateng, R.; Fricano, R.J.; Adarkwa, F. Assessing the Socio-Economic Impacts of Rural Road Improvements in Ghana: A Case Study of Transport Sector Program Support (II). Case Stud. Transp. Policy 2015, 3, 355-366. [CrossRef]

81. Wang, Z.; Sun, S. Transportation Infrastructure and Rural Development in China. China Agric. Econ. Rev. 2016, 8, 516-525. [CrossRef]

82. Kearns, R.A.; Lewis, N.; McCreanor, T.; Witten, K. “The Status Quo Is Not an Option”: Community Impacts of School Closure in South Taranaki, New Zealand. J. Rural Stud. 2009, 25, 131-140. [CrossRef]

83. Glick, P.; Sahn, D.E. The Demand for Primary Schooling in Madagascar: Price, Quality, and the Choice between Public and Private Providers. J. Dev. Econ. 2006, 79, 118-145. [CrossRef]

84. Brown, P.H.; Park, A. Education and Poverty in Rural China. Econ. Educ. Rev. 2002, 21, 523-541. [CrossRef]

85. Lyson, T.A. What Does a School Mean to a Community? Assessing the Social and Economic Benefits of Schools to Rural Villages in New York. J. Res. Rural Educ. 2002, 17, 131-137.

86. Casey, M.M.; Thiede Call, K.; Klingner, J.M. Are Rural Residents Less Likely to Obtain Recommended Preventive Healthcare Services? Am. J. Prev. Med. 2001, 21, 182-188. [CrossRef]

87. Langer, K.; Decker, T.; Menrad, K. Public Participation in Wind Energy Projects Located in Germany: Which Form of Participation Is the Key to Acceptance? Renew. Energy 2017, 112, 63-73. [CrossRef]

(C) 2017 by the authors. Licensee MDPI, Basel, Switzerland. This article is an open access article distributed under the terms and conditions of the Creative Commons Attribution (CC BY) license (http:/ / creativecommons.org/licenses/by/4.0/). 